\title{
Anti-inflammatory and toxicity studies of atranorin extracted from Cladina kalbii Ahti in rodents
}

\author{
Marcelia Garcez Dória de Melo', Adriano Antunes de Souza Araújo ${ }^{1 *}$, Mairim Russo Serafini', \\ Larissa Feitosa Carvalho', Marília Santos Bezerra ${ }^{1}$, Cledison Santos Ramos ${ }^{1}$, Leonardo Rigoldi \\ Bonjardim', Ricardo Luiz Cavalcanti Albuquerque-Júnior ${ }^{2}$, Julianeli Tolentino Lima ${ }^{3}$, Rosana Souza \\ Siqueira ${ }^{4}$, Vanessa Silveira Fortes ${ }^{4}$, Maria José Vieira Fonseca ${ }^{4}$, Lucindo José Quintans-Júnior ${ }^{1}$
}

\author{
${ }^{1}$ Departamento de Fisiologia, Universidade Federal de Sergipe, ${ }^{2}$ Laboratório de Morfologia e Biologia Estrutural, \\ Universidade Tiradentes, ${ }^{3}$ Núcleo de Estudos e Pesquisas de Plantas Medicinais, Universidade Federal do Vale do São \\ Francisco, ${ }^{4}$ Faculdade de Ciências Farmacêuticas de Ribeirão Preto, Universidade de São Paulo
}

\begin{abstract}
Atranorin (ATR) is the main compound from the lichen Cladina kalbii Ahti, which grows in the arid regions of northeastern Brazil. This study was conducted to evaluate the anti-inflammatory and toxicological properties of ATR. To evaluate anti-inflammatory properties, paw edema was induced by injecting 0.1 $\mathrm{mL}$ of carrageenan into the subplantar region of the right hind paw of rats, and leukocyte migration was induced by injection of $500 \mu \mathrm{L}$ of carrageenan into the peritoneal cavity of mice. In addition, we determined ATR cytotoxicity in L929 cells by MTT assay and acute $(5 \mathrm{~g} / \mathrm{kg}$-single dose) and subchronic ( $50 \mathrm{mg} / \mathrm{kg}$ 30 days) toxicity tests in Wistar rats. The results showed that ATR $(100 \mathrm{mg} / \mathrm{kg}$ and $200 \mathrm{mg} / \mathrm{kg})$ exhibited significant anti-inflammatory activity (paw edema and leukocyte migration). In the acute toxicity test, the animals showed hypoactivity and lethargy during the initial period (first 6 hours) and increase in total protein, total and indirect bilirubin, and alkaline phosphatase after 14 days in ATR-treated male rats. The subchronic toxicity test revealed increases in total protein, globulin, gamma-glutamyl transferase, alkaline phosphatase, and total and direct bilirubin in ATR-treated female rats. Histological analysis revealed no changes in the architecture and morphology of the organs. These results suggest that ATR has significant anti-inflammatory activity, with no significant acute and subchronic toxicity or cytotoxicity.
\end{abstract}

Uniterms: Cladina kalbii/pharmacognosy. Atranorin/anti-inflamatory activity. Atranorin/toxicity. Medicinal plants.

\begin{abstract}
Atranorina (ATR) é o principal composto do líquen Cladina kalbii Ahti, que cresce em terras áridas do nordeste brasileiro. Este estudo foi realizado para avaliar as propriedades antiinflamatórias e toxicológicas da ATR. Para avaliar as propriedades antiinflamatórias, o edema de pata foi induzido, administrando-se $0,1 \mathrm{~mL}$ de carragenina na região subplantar da pata traseira direita e a migração leucocitária foi induzida pela injeção de $500 \mu \mathrm{L}$ de carragenina no peritônio. Além disso, determinou-se a citotoxicidade da ATR, utilizando-se a linhagem celular L929, através do teste de MTT e dos testes de toxicidade aguda ( $5 \mathrm{~g} / \mathrm{kg}$ - dose única) e subcrônica ( $50 \mathrm{mg} / \mathrm{kg}$-30 dias) em ratos Wistar. Os resultados mostraram que nas doses de (100 mg/kg e $200 \mathrm{mg} / \mathrm{kg})$ a ATR exibiu atividade antiinflamatória significativa nos ensaios de edema de pata e migração leucocitária. Nos testes de toxicidade aguda, os animais apresentaram hipoatividade e letargia no período inicial (primeiras 6 horas) e aumento das proteínas totais, bilirrubinas total e indireta e fosfatase alcalina depois de 14 dias nos machos tratados. Para o ensaio subcrônico, houve aumento das proteínas totais, gama-glutamil-transferase, fosfatase alcalina e bilirrubina total e direta nas fêmeas tratadas com ATR. Não foram encontradas alterações na arquitetura e morfologia das lâminas histológicas observadas. Esses resultados sugerem que a ATR apresenta atividade antiinflamatória significativa, sem apresentar significativa toxicidade aguda, subcrônica e citotoxicidade.
\end{abstract}

Unitermos: Cladina kalbii/farmacognosia. Atranorina/atividade antiinflamatória. Atranorina/toxicidade. Plantas medicinais.

\footnotetext{
*Correspondence: A. A. S. Araújo. Departamento de Fisiologia, Universidade Federal de Sergipe - UFS. Av. Marechal Rondom, s/n, 49000-100 - São Cristóvão - Sergipe-Brazil. Tel.: +55-79-32126640; fax: +55-79-32126640. E-mail: adriasa2001@yahoo.com.br
} 


\section{INTRODUCTION}

Lichens are some of the most important sources of biologically active compounds (Barnes et al., 2000). They have a worldwide distribution and live in a symbiotic relationship with fungi (mycobiont), algae (phycobiont), and/or cyanobacteria (photobiont) (Honegger, 1991). This symbiosis provides physical protection, water, and mineral supply for both partners. They produce common intracellular constituents, including proteins, amino acids, polyols, carotenoids, polysaccharides, and vitamins. The secondary metabolites found in lichens are phenolics that accumulate either in the cortex or in the cell walls of medullary hyphae, and they are mainly acetyl-polymalonyl pathway derivatives (Honda, Vilegas, 1999). Furthermore, lichens are able to synthesize several metabolites, which are composed of aliphatic, cycloaliphatic, aromatic, and terpenic compounds (Huneck, 1999).

Polysaccharides, proteins, and secondary metabolites produced by lichens have attracted the attention of investigators due to their biological activities. For centuries, a number of the 17,000 known lichen species have been used by humans for medicinal purposes. In the northeastern region of Brazil, lichen species vary according to the environment, from the coastal zone (humid) to the inner region, where the climate is semi-arid (caatinga). In these habitats, several species are considered to be bioactive (Maia et al., 2002; Pereira, 1996). Atranorin (ATR) (Figure 1) is the main compound from the lichen Cladina kalbii Ahti, which grows in the arid regions of northeastern Brazil. ATR is an important member of the depside group. The molecular structures of these depsides present aromatic esters with a methyl ester terminal group (Howell et al., 2003).

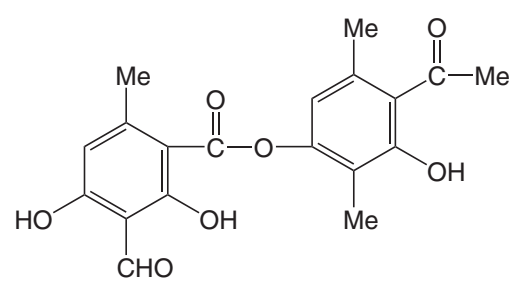

FIGURE 1 - Chemical structure of atranorin.

Studies on the pharmacological properties of $C$. kalbii and its constituents have revealed antinociceptive effects (Pereira, 1996; Maia et al., 2002), antimicrobial action against Staphylococcus aureus and Bacillus subtilis (Falcão et al., 2004; Ribeiro et al., 2002), and photoprotection capacity (Fernandez et al., 1998) as well as antioxidant activity (Hidalgo et al., 1994). Additionally, a recent report has demonstrated the antinociceptive property of ATR in mice (Melo, 2008; Siqueira et al., 2010). Despite the widespread medicinal use of $C$. kalbii root extracts in Brazil and elsewhere, there are no published studies on their toxicological and anti-inflammatory properties.

This study aimed to evaluate the anti-inflammatory activity, cytotoxicity, and toxic effects of acute (single dose) and subchronic (30 days) oral administration of ATR extracted from $C$. kalbii in rodents.

\section{MATERIAL AND METHODS}

\section{Lichen material}

C. kalbii was collected in March 2007 in Itabaiana, State of Sergipe, Northeastern Brazil (10 $44^{\prime}$ 'S, 37 $\left.23^{\circ} \mathrm{W}\right)$, and identified by M.P. Marcelli (Botanical Institute of São Paulo-SP, Brazil). SP 393235.

\section{Extraction and isolation of ATR}

ATR $\left(\mathrm{C}_{19} \mathrm{H}_{18} \mathrm{O}_{8}\right)$ was isolated from the crude extract of the lichen $C$. kalbii. The air-dried parts $(100 \mathrm{~g})$ of $C$. kalbii were extracted with $150 \mathrm{~mL}$ of chloroform using a Soxhlet apparatus to isolate ATR. The crude extract was filtered and stored at $4{ }^{\circ} \mathrm{C}$ for $24 \mathrm{~h}$ for ATR precipitation.

\section{Animals}

Male and female Wistar rats (150-200 g) and male Swiss mice (28-32 g) were obtained from Universidade Federal de Sergipe, Brazil. Toxicity tests were performed in male and female rats and anti-inflammatory tests were performed only in male rats or mice. The animals were kept under standard laboratory conditions $\left(20 \pm 2{ }^{\circ} \mathrm{C}\right)$ and housed in polypropylene cages, with food and water ad libitum. All experimental protocols were approved by the Institutional Animal Care and Use Committee of Universidade Federal de Sergipe (CEPA/UFS 100/2006). All experiments were performed from 1:00 p.m. to 6:00 p.m.

\section{Anti-inflammatory study}

\section{Carrageenan-induced hind paw edema in rats}

Acute hind paw edema was induced in male rats by injecting $0.1 \mathrm{~mL}$ of carrageenan (prepared as $1 \%$ suspension in sterile normal saline) into the subplantar region of the right hind paw (Winter et al., 1962). ATR (50, 100, and $200 \mathrm{mg} / \mathrm{kg}$, p.o.) was administered to three different groups, while two other groups served as negative and positive controls and received vehicle $(0.9 \%$ saline with two drops 
of $0.2 \%$ Tween 80 , a solvent for ATR) and standard drug (aspirin, $300 \mathrm{mg} / \mathrm{kg}$, p.o.), respectively. ATR and aspirin were administered $1 \mathrm{~h}$ prior to the injection of carrageenan. The rat pedal volume up to the ankle joint was measured using a plethysmometer (Model LE 7500 Panlab, Barcelona, Spain) at $3 \mathrm{~h}$ after the injection of carrageenan.

\section{Leukocyte migration to the peritoneal cavity}

Leukocyte migration was induced by injection of $500 \mu \mathrm{L}$ of carrageenan $(500 \mu \mathrm{g} /$ cavity, i.p.) into the peritoneal cavity of male mice $1 \mathrm{~h}$ after administration of ATR $(50,100$, and $200 \mathrm{mg} / \mathrm{kg}$, p.o.), vehicle $(0.9 \%$ saline with two drops of $0.2 \%$ Tween 80$)$, or dexamethasone $(2 \mathrm{mg} / \mathrm{kg}$, s.c., $\mathrm{n}=6$ ) by a modification of the technique previously described by Bastos et al. (2007). Mice were euthanized by cervical dislocation $4 \mathrm{~h}$ after carrageenan injection. Shortly after, phosphate-buffered saline (PBS) containing EDTA $(1 \mathrm{mM}$, i.p., $10 \mathrm{~mL})$ was injected. Immediately after, the abdomen was briefly massaged for further fluid collection, which was centrifuged (2000 rpm, $5 \mathrm{~min}$ ) at room temperature. The supernatant was disposed and $1 \mathrm{~mL}$ of PBS was added to the precipitate. A $10-\mu \mathrm{L}$ aliquot of this suspension was diluted in $200 \mu \mathrm{L}$ of Turk solution, and total cells were counted in a Neubauer chamber under optical microscopy. The results were expressed as the number of leukocytes $/ \mathrm{mL}$. The percentage of leukocyte inhibition (\%LI) was calculated as follows: $\% \mathrm{LI}=(1-\mathrm{T} / \mathrm{C}) \times 100$, where T represents the test groups' leukocyte counts, and $\mathrm{C}$ represents the control groups' leukocyte counts.

\section{Toxicological studies}

\section{Subchronic toxicity study}

Toxicological assays were performed with 20 male and 20 female rats, divided into 4 groups of 10 animals each (experimental and control groups of male and female rats) (BRASIL, 2004). For the subchronic study, daily doses of ATR $(50 \mathrm{mg} / \mathrm{kg})$ dissolved in saline with $0.2 \%$ Tween 80 (vehicle) were administered to the experimental groups over a 30-day period, whereas the controls received only saline.

At the end of the experimental period, and after a $12 \mathrm{~h}$ fast, the animals were anesthetized with thiopental $(50 \mathrm{mg} / \mathrm{kg})$ and blood $(3-5 \mathrm{~mL})$ was collected from the abdominal aorta. Subsequently, the animals were sacrificed (hemorrhagic shock) and a detailed study of the gross and microscopic features of internal organs as well as hematological and biochemical analyses of blood were carried out. The position, shape, size, texture, consistency, and color of internal organs (lungs, heart, liver, viscera, and kidneys) were macroscopically examined for any signs of gross changes. These organs were then collected, weighed to determine relative organ weights, and fixed in $10 \%$ phosphate-buffered formalin solution for subsequent histological procedures.

\section{Acute toxicity study}

Toxicological assays were performed with 12 male and 12 female rats, divided into 4 groups of 6 animals each (experimental and control groups of male and female rats) (BRASIL, 2004). The animals received $5 \mathrm{~g} / \mathrm{kg}$ of ATR by oral administration (gavage). ATR, dissolved in saline with $0.2 \%$ Tween 80 (vehicle), was administered to the experimental groups, whereas the controls received only saline.

Specific behaviors (sedation, reduced ambulation, response to touch, analgesia, and defecation) were observed and graded according to Almeida et al. (1999) at 1, 2,3 , and $4 \mathrm{~h}$ after gavage. Finally, the animals were monitored daily for 14 days to verify lethality. At the end of the experimental period, and after a $12 \mathrm{~h}$ fast, the animals were anesthetized with thiopental and blood was collected from the abdominal aorta. Subsequently, the animals were sacrificed (hemorrhagic shock) and a detailed study of the gross and microscopic features of internal organs as well as hematological and biochemical analyses of blood were carried out. The position, shape, size, texture, consistency, and color of internal organs (lungs, heart, liver, viscera, brain, and kidneys) were macroscopically examined for any signs of gross changes. These organs were then collected, weighed to determine relative organ weights, and fixed in $10 \%$ phosphate-buffered formalin solution for subsequent histological procedures.

\section{Parameters}

\section{Hematological analysis}

Blood samples were collected into EDTA tubes. Measurements of erythrocytes, hemoglobin, hematocrit, leukocyte, neutrophil, lymphocyte, eosinophil, monocyte, basophil, atypical lymphocyte, and platelets were determined using Pentra-120 (ABX-HORIBA) automated equipment according to the method described by Morris and Davey (1999).

\section{Biochemical parameters}

Serum was separated from non-heparinized blood and assayed for serum urea, creatinine, total protein, globulin, albumin, aspartate aminotransferase (AST), alanine aminotransferase (ALT), gamma-glutamyl transferase (GGT), total bilirubin (TBIL), direct bilirubin (DBIL), alkaline phosphatase (ALP), lactate dehydrogenase (LDH), calcium, sodium, potassium, and uric acid. Biochemical 
parameters were determined using Dade Behring Dimension $\mathrm{RxL}$ automated equipment.

\section{Tissue analysis}

Formalin-fixed samples of internal organs were dehydrated, cleared, and embedded in paraffin according to standard histological procedures. Then, $5 \mu$-thick sections of paraffin-embedded tissues were obtained and stained with hematoxylin-eosin. Morphological analysis of the histological sections was performed by light microscopy in a blinded fashion, following a numerical protocol so that the pathologist was blinded to treatment groups until the end of the experiment. Morphometric analysis was used to compare mean kidney glomerular perimeter between female rats (control and test groups). The images were digitized using 5 histological fields for each case (200x magnification), employing an Olympus image capture system. The digital images were then processed using specific morphometry software (Image Tool 3.0).

\section{Determination of cytotoxicity}

L929 cells (fibroblast cells) from the Rio de Janeiro Cell Bank, University of Rio de Janeiro, Rio de Janeiro, Brazil, were routinely grown in $150 \mathrm{~cm}^{2}$ tissue culture flasks in DMEM supplemented with $1 \%(\mathrm{v} / \mathrm{v})$ of an antibiotic solution containing $5 \mathrm{mg}$ of penicillin, $5 \mathrm{mg}$ of streptomycin and $10 \mathrm{mg}$ of neomycin per $\mathrm{mL}$, and $7.5 \%$ or $10.0 \%(\mathrm{v} / \mathrm{v})$ heat-inactivated fetal bovine serum at $37^{\circ} \mathrm{C}$ under $5 \% \mathrm{CO}_{2}$.

\section{MTT assay}

Cell sensitivity to ATR was determined by standard spectrophotometric 3-(4,5-dimethylthiazol-2-yl)-2,5diphenyltetrazolium bromide (MTT) assay. Cells were seeded at a density of $10^{5}$ cells/well into 96-well plates and incubated for $24 \mathrm{~h}$ at $37^{\circ} \mathrm{C}$ in a $95 \%$ air, $5 \% \mathrm{CO}_{2}$ atmosphere. Then, $20 \mu \mathrm{L}$ of ATR at different concentrations in PBS was added to the culture plates for $24 \mathrm{~h}$. After treatment, cells were rinsed once with PBS. Serum-free culture medium, without phenol red, was added back to all wells. Cells were then incubated for $4 \mathrm{~h}$ with MTT solution (5 $\mathrm{mg} / \mathrm{mL}$ ). The yellow tetrazolium salt was metabolized by viable cells to form purple formazan crystals. The crystals were solubilized overnight $(12 \mathrm{~h})$ in a mixture consisting of $20 \%$ sodium dodecyl sulfate (SDS) in $\mathrm{HCl}(0.01 \mathrm{M})$. The product was quantified spectrophotometrically by measuring absorbance at $570 \mathrm{~nm}$ using a microplate reader $\left(\mu\right.$ uant $^{\mathrm{TM}}$, BioTek Instruments Inc., USA). Cell viability was expressed as the percentage of viable cells in relation to the control cells.

\section{Statistical analysis}

The Student $t$ test was employed in the statistical analysis of the results (Origin 6.2 or GraphPad Prism 4.01). Data obtained from the anti-inflammatory study were evaluated by one-way analysis of variance (ANOVA), followed by Dunnett's or Fisher's tests. All values were expressed as back-transformed mean \pm standard deviation (SD). Differences between groups were considered statistically significant at $\mathrm{p}<0.05$.

\section{RESULTS AND DISCUSSION}

\section{Anti-inflammatory study}

The mean increase in paw edema volume was about $0.82 \pm 0.17 \mathrm{~mL}$ in vehicle-treated rats. ATR (100 and $200 \mathrm{mg} / \mathrm{kg}$, p.o.) significantly reduced $(\mathrm{p}<0.05)$ mean paw edema volume (29.3 and 32.9\%, respectively), as compared with the control group, at $3 \mathrm{~h}$ after carrageenan injection. Similarly, aspirin (300 mg/kg, p.o.) showed highly significant $(\mathrm{p}<0.001)$ anti-inflammatory activity, with a $76.4 \%$ inhibition rate (Table I).

Several mediators are released by carrageenan in the rat paw. The initial phase of the response to carrageenan may be due to the release of histamine and serotonin, whereas kinins may play a role in the middle phase (Di Rosa, Sorrentino, 1968), and prostaglandins may be the most important mediators in the final 3-5 h of the post-carrageenan response (Vinegar et al., 1969). Bugni et al. (2009) showed that part of the antinociceptive effect obtained with ATR may be due to inhibition of cyclooxygenase (COX) enzymes. Additionally, Siqueira et al. (2010) suggested that ATR modulates neurogenic and inflammatory pain in capsaicin- and formalin-induced orofacial pain test models through a naloxone-sensitive mechanism.

Figure 2 shows the inhibitory effect of ATR on carrageenan-induced leukocyte migration into the peritoneal cavity $4 \mathrm{~h}$ after stimulus at all doses $(31.9,35.9$, and $42.5 \%$ at doses of 50,100 , and $200 \mathrm{mg} / \mathrm{kg}$, respectively; $\mathrm{p}<0.05$ ). The results obtained with the control group support the effect of ATR, since the vehicle showed no activity and the control drug (dexamethasone, $2 \mathrm{mg} / \mathrm{kg}$, s.c.) inhibited leukocyte migration $(92.2 \%, \mathrm{p}<0.001)$, as compared with the control group.

Cell recruitment during inflammation depends on the orchestrated release of local mediators responsible for local vascular and tissue changes as well as for the recruitment of host defense cells (Luster et al., 2005). Inflammation induced by carrageenan involves cell migration, 
TABLE I - Effect of atranorin (ATR) or aspirin on carrageenan-induced hind paw edema in rats $(n=8)$

\begin{tabular}{lccc}
\hline Treatment & Dose $(\mathrm{mg} / \mathrm{kg})$ & $\begin{array}{c}\text { Carrageenan-induced hind paw } \\
\text { edema volume }(\mathrm{mL})^{\mathrm{a}}\end{array}$ & \% inhibition \\
\hline Vehicle & - & $0.82 \pm 0.17$ & - \\
ATR & 50 & $0.77 \pm 0.15$ & 6.1 \\
ATR & 100 & $0.58 \pm 0.11^{\mathrm{b}}$ & $29.3^{\mathrm{d}}$ \\
ATR & 200 & $0.55 \pm 0.08^{\mathrm{b}}$ & $32.9^{\mathrm{d}}$ \\
Aspirin & 300 & $0.21 \pm 0.05^{\mathrm{c}}$ & $76.4^{\mathrm{e}}$ \\
\hline
\end{tabular}

${ }^{a}$ Values expressed as mean \pm standard error of the mean (SEM).

${ }^{\mathrm{b}} \mathrm{P}<0.05$ (one-way ANOVA and Dunnett's test), significantly different from control.

${ }^{c} \mathrm{P}<0.001$ (one-way ANOVA and Dunnett's test), significantly different from control.

${ }^{\mathrm{d}} \mathrm{P}<0.05$ (Fisher's test), significantly different from control.

${ }^{\mathrm{e}} \mathrm{P}<0.001$ (Fisher's test), significantly different from control.

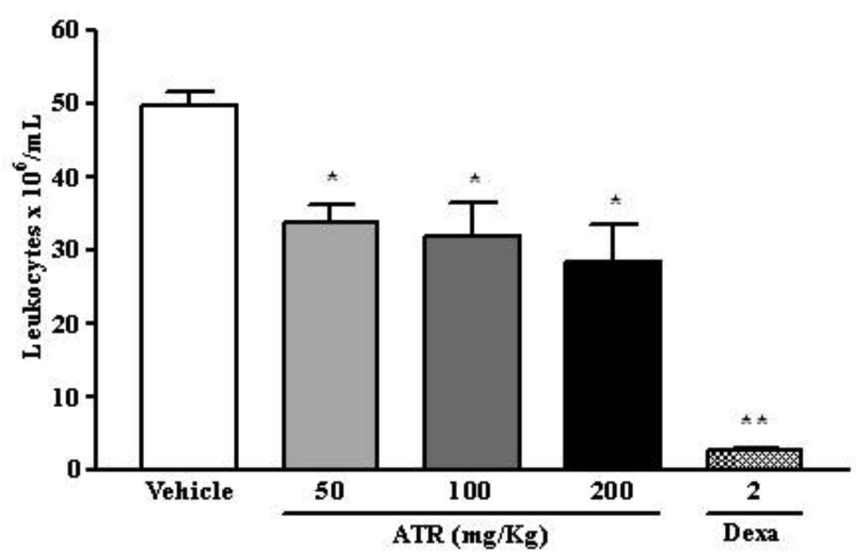

FIGURE 2 - Effect of atranorin (ATR) on carrageenan-induced leukocyte migration into the peritoneal cavity in mice. Groups of mice were pretreated with vehicle (control group, $10 \mathrm{~mL} / \mathrm{kg}$, p.o.), dexamethasone (Dexa, $2 \mathrm{mg} / \mathrm{kg}$, s.c.), or ATR at concentrations of 50,100 , and $200 \mathrm{mg} / \mathrm{kg}$ (p.o.) $60 \mathrm{~min}$ before carrageenan (500 $\mu \mathrm{g} / \mathrm{cavity}, 500 \mu \mathrm{L}$, i.p.)-induced peritonitis. Cell counts were performed at $4 \mathrm{~h}$ after injection of carrageenan. Values are expressed as mean \pm standard error of the mean (SEM). ${ }^{*} \mathrm{p}<0.05$ and $* * \mathrm{p}<0.001$ when compared to control group. ANOVA followed by Dunnett's test ( $n=6$, per group).

plasma exudation, and production of chemical mediators, such as nitric oxide, prostaglandin E2, interleukin (IL)-1 $\beta$, IL-6, and tumor necrosis factor (TNF)- $\alpha$ (Salvemini et al., 1996; Loram et al., 2007). Those mediators are able to recruit leukocytes, such as neutrophils, as demonstrated in several experimental models.

Kumar and Muller (1999) demonstrated that ATR effectively inhibits the biosynthesis of leukotriene B4 in bovine polymorphonuclear leukocytes, which could also lead to an anti-inflammatory effect. Because ATR inhibited carrageenan-induced paw edema volume and leukocyte migration, it may be suggested that these activities are related to inhibition of the synthesis of many inflammatory mediators, whose involvement in cell migration is well established.

\section{Subchronic toxicity study}

Administration of ATR $(50 \mathrm{mg} / \mathrm{kg}$, p.o.) for 30 days did not modify the profile of weight gain when test and control groups were compared (Figure 3 ). In addition, food and water consumption for control and treated animals was kept within the established limits for this animal species.

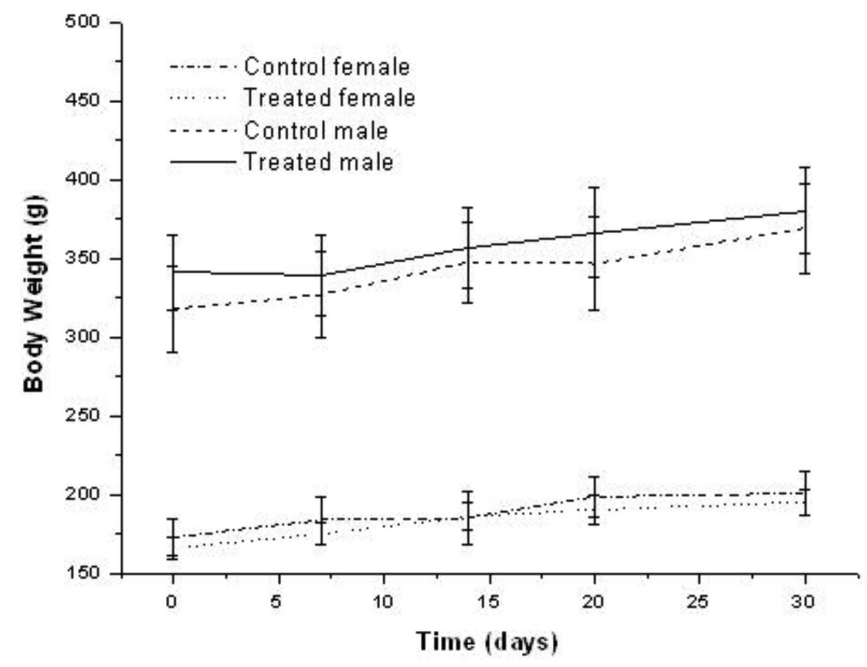

FIGURE 3 - Changes in rat body weight during 30-day atranorin (ATR) treatment $(50 \mathrm{mg} / \mathrm{kg})$. Each point represents mean \pm standard deviation $(\mathrm{SD})$ of $\mathrm{n}=10$.

There were no changes in the weight of lungs, heart, liver, and stomach (Table II) 30 days after subchronic treatment with $50-\mathrm{mg} / \mathrm{kg}$ ATR. The internal organs of both control and treated animals showed no unusual signs. 
Moreover, both macro and microscopic analyses revealed normal findings. The organs of both control and treated groups were unremarkable and comparable to each sex. There was no further evidence of histopathological changes. The architecture and cell appearance of the examined internal organs were comparatively unremarkable in both groups and sexes. Only the female rats showed significant differences in the relative weight of the kidneys, as shown in Table II.

Thus, a morphometric analysis was performed in the kidney glomerular cells, which showed no significant differences when compared to test and control groups. Scientific literature on the renal histology and morphometry of animals treated with lichens is still rare. The differences in kidney weights could suggest a renal reduction in the area of glomerular corpuscle and capsular space (Daniels, Hostetter, 1990). However, gross and microscopic pathologic examination of the kidneys detected no abnormalities. Also, the values observed for kidney weight are consistent with the limits considered normal for this animal species, according to Hossne et al. (1986).

Results of the hematological study are presented in Table III. The data show that hemoglobin, hematocrit, leukocyte, neutrophil, lymphocyte, eosinophil, monocyte, basophil, atypical lymphocyte, and platelet levels for the control rats were not significantly different from

TABLE II - Changes in organ weight of rats after subchronic oral treatment with atranorin (ATR) at a daily dose of $50 \mathrm{mg} / \mathrm{kg}$ for 30 days

\begin{tabular}{lccccc}
\hline \multicolumn{7}{c}{ Organ weight } \\
\hline Groups & Lung $(\mathrm{g})$ & Heart $(\mathrm{g})$ & Liver $(\mathrm{g})$ & Kidneys $(\mathrm{g})$ & Stomach $(\mathrm{g})$ \\
\hline CF & $1.52 \pm 0.21$ & $0.81 \pm 0.09$ & $7.45 \pm 0.85$ & $1.91 \pm 0.28$ & $3.85 \pm 0.99$ \\
TF & $1.45 \pm 0.13$ & $0.77 \pm 0.08$ & $7.43 \pm 0.50$ & $1.54 \pm 0.09^{*}$ & $3.95 \pm 0.70$ \\
CM & $2.39 \pm 0.26$ & $1.45 \pm 0.20$ & $9.97 \pm 2.03$ & $3.01 \pm 0.31$ & $8.84 \pm 1.25$ \\
TM & $2.54 \pm 0.31$ & $1.47 \pm 0.20$ & $9.98 \pm 1.11$ & $2.88 \pm 0.22$ & $9.36 \pm 1.60$ \\
\hline
\end{tabular}

$\mathrm{CF}=$ control female; $\mathrm{CM}=$ control male; $\mathrm{TF}=$ treated female; $\mathrm{TM}=$ treated male.

Data are expressed as mean \pm standard deviation (SD), $\mathrm{n}=10$.

* Indicates statistical difference between control and ATR groups $(\mathrm{p}<0.05)$.

TABLE III - Effect of 30-day oral administration of atranorin (ATR) on hematological parameters, considering sex interaction, in Wistar rats $(\mathrm{n}=10)$

\begin{tabular}{lcccccc}
\hline \multicolumn{7}{c}{ Groups } \\
\hline Parameters & CF & TF & $\begin{array}{c}\text { UFS Female } \\
\text { Vivarium }\end{array}$ & CM & TM & $\begin{array}{c}\text { UFS Male } \\
\text { Vivarium }\end{array}$ \\
\hline Erythrocytes $\left(\times 10^{6} / \mathrm{mm}^{3}\right)$ & $8.32 \pm 0.17$ & $8.14 \pm 0.40$ & $7.3-8.64$ & $8.28 \pm 0.58$ & $7.74 \pm 0.42 *$ & $6.7-8.6$ \\
Hemoglobin $(\mathrm{g} / \mathrm{dl})$ & $14.10 \pm 0.33$ & $13.83 \pm 0.52$ & $13.2-15.1$ & $15.94 \pm 0.77$ & $15.33 \pm 0.56$ & $12.8-15.9$ \\
Hematocrit $(\%)$ & $42.93 \pm 0.94$ & $41.76 \pm 1.86$ & $39.1-48.5$ & $45.55 \pm 3.48$ & $42.57 \pm 3.15$ & $39.1-48.7$ \\
Leukocyte $\left(\times 10^{3} / \mathrm{mm}^{3}\right)$ & $6.41 \pm 1.00$ & $7.07 \pm 0.97$ & $4.7-12.98$ & $7.72 \pm 1.43$ & $7.25 \pm 1.83$ & $5.7-13.9$ \\
Neutrophil $(\%)$ & $4.12 \pm 1.24$ & $4.11 \pm 0.33$ & $5.4-37.5$ & $20.40 \pm 6.83$ & $18.33 \pm 4.21$ & $17.1-47.9$ \\
Lymphocyte $(\%)$ & $94 \pm 1.77$ & $94.11 \pm 0.60$ & $57.9-90.0$ & $65.90 \pm 7.04$ & $68.55 \pm 3.20$ & $48.7-78.1$ \\
Eosinophil $(\%)$ & 0 & 0 & $0.2-4.5$ & 0 & 0 & $0.3-4.0$ \\
Monocyte $(\%)$ & $1.25 \pm 0.46$ & 1 & $0.6-7.9$ & $13.7 \pm 2.40$ & $13.11 \pm 1.69$ & $1.0-6.5$ \\
Basophil $(\%)$ & $0.5 \pm 0.53$ & $0.66 \pm 0.50$ & $0-0.8$ & 0 & 0 & $0-0.8$ \\
Atypical lymphocyte $(\%)$ & $0.12 \pm 0.35$ & $0.11 \pm 0.33$ & $0-1.0$ & 0 & 0 & $0-1.0$ \\
Platelets $\left(\times 10^{3} / \mathrm{mm}^{3}\right)$ & $9627.5 \pm 58.21$ & $9940.00 \pm 72.83$ & $757-1476$ & $7352 \pm 20.13$ & $7352 \pm 25.84$ & $837-1455$ \\
\hline CF cont
\end{tabular}

$\mathrm{CF}=$ control female; $\mathrm{CM}=$ control male; $\mathrm{TF}=$ treated female; $\mathrm{TM}=$ treated male; UFS = Universidade Federal de Sergipe, Northeastern Brazil.

Data are expressed as mean \pm standard deviation (SD), $\mathrm{n}=10$.

* Indicates statistical difference between control and ATR groups $(\mathrm{p}<0.05)$. 
those of ATR-treated rats during the study period (Table III). Only erythrocyte counts were significantly lower in treated males 30 days after treatment, as compared to the control group ( $\mathrm{p}<0.05)$. However, these values could be considered normal because, according to Schalm (1986), the number of erythrocytes may range from 5.25 to 8.5 million in male rats. Furthermore, these values are also in agreement with the reference values for rats in the university vivarium (these reference values were determined in a recent survey, but such data are not yet published).

The increase in erythrocytes may be due to overproduction of hematopoietic regulatory elements, such as colony-stimulating factors, erythropoietin, and thrombopoietin, by stromal cells and macrophages in the bone marrow (Chang-Gue et al., 2003), thus providing a local environment for hematopoiesis (Udut et al., 2005). In addition, the fact that such a significant difference was not verified between the female groups supports the idea that this finding is merely contingent.
Plasma biochemical data are described in Table IV. No significant changes were observed in urea, creatinine, albumin, AST, ALT, LDH, calcium, sodium, potassium, and uric acid. Nevertheless, the study showed an increase in total protein and globulin, demonstrating that liver function was preserved (Motta, 2003). Furthermore, the increase in GGT, DBIL, and ALP revealed biliary cholestasis (Henry, 2008), probably due to an incipient inflammatory process.

The histopathological examination of selected organs (lungs, heart, liver, viscera, and kidneys) from treated and control animals showed normal architecture, suggesting that daily oral administration of ATR for 30 days caused no detrimental changes or morphological disturbances.

\section{Acute toxicity study}

In the acute toxicity test, doses of $5 \mathrm{~g} / \mathrm{kg}$ of ATR

TABLE IV - Serum biochemical findings in rats treated with atranorin (ATR) at a daily dose of $50 \mathrm{mg} / \mathrm{kg}$ for 30 days

\begin{tabular}{|c|c|c|c|c|c|c|}
\hline \multicolumn{7}{|c|}{ Groups } \\
\hline Parameters & $\mathrm{CF}$ & $\mathrm{TF}$ & $\begin{array}{l}\text { UFS Female } \\
\text { Vivarium }\end{array}$ & $\mathrm{CM}$ & $\mathrm{TM}$ & $\begin{array}{l}\text { UFS Male } \\
\text { Vivarium }\end{array}$ \\
\hline Urea (mg/dL) & $58.80 \pm 33.40$ & $43.70 \pm 5.91$ & $30-57$ & $37.30 \pm 4.16$ & $33.70 \pm 4.08$ & $30-42$ \\
\hline Creatinine (mg/dL) & $0.40 \pm 0.22$ & $0.41 \pm 0.09$ & $0.4-0.7$ & $0.40 \pm 0.04$ & $0.33 \pm 0.11$ & $0.44-0.64$ \\
\hline Total protein $(\mathrm{g} / \mathrm{dL})$ & $6.10 \pm 0.40$ & $6.43 \pm 0.27^{*}$ & $6.1-7.4$ & $5.38 \pm 0.32$ & $5.47 \pm 0.22$ & $5.4-6.6$ \\
\hline Globulin (g/dL) & $4.71 \pm 0.39$ & $5.12 \pm 0.21^{*}$ & $3.1-4.3$ & $4.36 \pm 0.24$ & $4.44 \pm 0.16$ & $2.7-3.5$ \\
\hline Albumin (g/dL) & $1.32 \pm 0.05$ & $1.31 \pm 0.07$ & $2.6-3.4$ & $1.02 \pm 0.10$ & $1.03 \pm 0.09$ & $2.7-3.2$ \\
\hline AST (U/L) & $77.33 \pm 11.21$ & $68.33 \pm 6.74$ & $83-184$ & $122.22 \pm 45.46$ & $100.74 \pm 18.63$ & $81-180$ \\
\hline $\operatorname{ALT}(\mathrm{U} / \mathrm{L})$ & $63.75 \pm 17.46$ & $74.36 \pm 7.07$ & $26-60$ & $70.87 \pm 23.7$ & $60.88 \pm 9.31$ & $36-58$ \\
\hline GGT (U/L) & $8.79 \pm 1.39$ & $12.11 \pm 1.26^{*}$ & -- & $8.91 \pm 1.37$ & $8.82 \pm 0.91$ & - \\
\hline TBil (mg/dL) & $0.07 \pm 0.02$ & $0.12 \pm 0.02 *$ & $0.07-0.09$ & $0.25 \pm 0.05$ & $0.24 \pm 0.03$ & $0.07-0.08$ \\
\hline DBil (mg/dL) & $0.02 \pm 0.01$ & $0.05 \pm 0.01 *$ & $0.01-0.03$ & $0.17 \pm 0.01$ & $0.16 \pm 0.01$ & $0.01-0.03$ \\
\hline IBil (mg/dL) & $0.04 \pm 0.02$ & $0.06 \pm 0.01 *$ & $0.01-0.01$ & $0.5 \pm 0.28$ & $0.39 \pm 0.28$ & $0.01-0.01$ \\
\hline ALP(U/L) & $100.8 \pm 46.84$ & $156.8 \pm 36.52 *$ & $63-138$ & $89.27 \pm 28.0$ & $73.49 \pm 7.04$ & $79-196$ \\
\hline LDH & $305.1 \pm 89.71$ & $219 \pm 116.29$ & -- & $1270.5 \pm 14.84$ & $979.00 \pm 318.4$ & -- \\
\hline $\mathrm{Ca}^{2+}(\mathrm{mEq} / \mathrm{L})$ & $9.83 \pm 0.48$ & $10.08 \pm 0.48$ & & $10.42 \pm 0.28$ & $10.53 \pm 0.35$ & -- \\
\hline $\mathrm{Na}^{+}(\mathrm{mEq} / \mathrm{L})$ & $142.3 \pm 10.78$ & $145.55 \pm 1.23$ & $135-144$ & $140.23 \pm 1.31$ & $140.00 \pm 0.83$ & $132-146$ \\
\hline $\mathrm{K}^{+}(\mathrm{mEq} / \mathrm{L})$ & $4.46 \pm 1.12$ & $4.31 \pm 0.76$ & $4.2-6.4$ & $5.79 \pm 1.55$ & $5.81 \pm 0.58$ & $3.7-5.7$ \\
\hline Uric acid (mg/dL) & $1.44 \pm 0.57$ & $1.41 \pm 0.80$ & $0.9-2.0$ & $2.49 \pm 1.26$ & $2.02 \pm 0.54$ & $0.9-2.0$ \\
\hline
\end{tabular}

$\mathrm{ALP}=$ alkaline phosphatase; $\mathrm{ALT}=$ alanine aminotransferase; $\mathrm{AST}=$ aspartate aminotransferase; $\mathrm{CF}=$ control female; $\mathrm{CM}=$ control male; $\mathrm{DBil}=$ direct bilirubin; GGT = gamma-glutamyl transferase; IBil = indirect bilirubin; $\mathrm{LDH}=$ lactate dehydrogenase; $\mathrm{TBil}=$ total bilirubin; $\mathrm{TF}=$ treated female; $\mathrm{TM}=$ treated male; UFS $=$ Universidade Federal de Sergipe, Northeastern Brazil.

Data are expressed as mean \pm standard deviation $(\mathrm{SD}), \mathrm{n}=10$.

* Indicates statistical difference between control and ATR groups $(\mathrm{p}<0.05)$. 
caused no deaths in rats during a 14-day observation period. The rats showed no signs of toxicity or changes in general behavior or any other physiological activities. Except for reduced locomotor activity ('hypoactivity') and lethargy, observed within the first 24 hours of ATR administration (at a single dose of $5 \mathrm{~g} / \mathrm{kg}$ ), no other signs of toxicity were noted in rats treated with oral ATR. Figure 4 shows a graphical representation of changes in body weight following the treatment of rats with ATR and saline. There was a significant increase $(p<0.05)$ in body weight over the experimental period for all treatment groups.

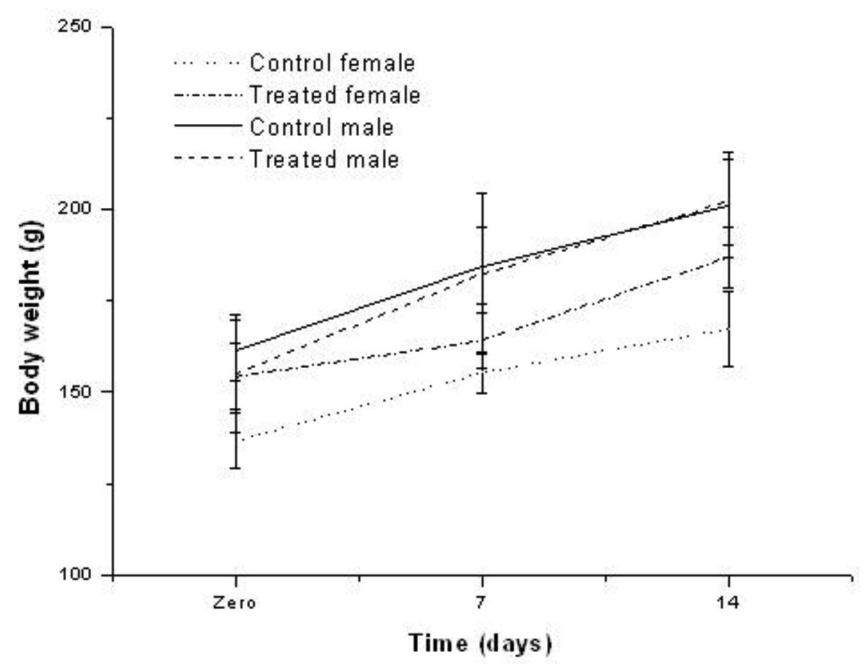

FIGURE 4 - Changes in rat body weight during atranorin (ATR) treatment ( $5 \mathrm{~g} / \mathrm{kg}$-single dose). Each point represents mean \pm standard deviation (SD) of $\mathrm{n}=10$.

As shown in Table V, organ weights (lung, heart, liver, viscera, and brain) of ATR-treated rats did not differ from those of the control group.

Hematological analysis in the acute study (Table VI) showed no significant differences in the parameters examined in control or treated animals of both sexes. At a dose of $5 \mathrm{~g} / \mathrm{kg}$ (single dose), only the male group showed a significant decrease in lymphocyte (\%), as compared with the corresponding control group. In contrast, there was no significant change in any of the differential lymphocyte counts in female rats. Moreover, the difference noted in lymphocyte count between groups is within the reference values given by Mitruka and Rawnsley (1981), 65-84.5\%, suggesting the absence of clinically relevant alterations.

The biochemical profile of treated and control rats is presented in Table VII. Acute oral administration of ATR (5 g/kg-single dose) only altered bilirubin levels, with no significant changes in serum urea, creatinine, globulin, AST, ALT, GGT, DHL, calcium, potassium, and uric acid. Because of a significant increase in TBIL and DBIL alone, it may be suggested that a reduction in conjugation rate occurs within the hepatocyte (Henry, 2008). Altered ALP and sodium levels in the male group were considered normal, since they are in agreement with the reference values for rats in the university vivarium. In addition, no abnormalities or further evidence of histopathological changes were found in any of control or treated rats of both sexes.

Gross pathologic examination of the tissues detected no abnormality in weight or appearance between control and experimental groups. Moreover, the organs of both groups were unremarkable and comparable to each sex. Microscopic analysis revealed that the architecture and cell appearance of the internal organs were comparatively unremarkable in both groups and sexes. These findings indicate that oral administration of purified ATR extracted from C. kalbii promotes no morphological changes in the vital organs of animals and suggest that this substance provides no toxicological effects.

\section{Determination of cytotoxicity}

MTT is a water-soluble tetrazolium salt, which is converted to an insoluble purple formazan product by cleavage of the tetrazolium ring by succinate dehydrogenase activity within the mitochondria. The formazan product is impermeable to cell membranes and therefore accumulates in healthy cells (Fotakis, Timbrell, 2006).

ATR was evaluated in a mouse fibroblast cell line (L929) in order to examine its cytotoxic effects on normal

TABLE V - Changes in organ weight of rats after acute oral treatment with atranorin (ATR) at a daily dose of $5 \mathrm{~g} / \mathrm{kg}$ (single dose)

\begin{tabular}{lcccccc}
\hline Groups & Lung $(\mathrm{g})$ & Heart $(\mathrm{g})$ & Liver $(\mathrm{g})$ & Kidneys $(\mathrm{g})$ & Viscera $(\mathrm{g})$ & Brain $(\mathrm{g})$ \\
\hline $\mathrm{CF}$ & $1.28 \pm 0.02$ & $0.61 \pm 0.03$ & $5.75 \pm 0.33$ & $1.35 \pm 0.02$ & $4.45 \pm 0.07$ & $1.30 \pm 0.12$ \\
$\mathrm{TF}$ & $1.15 \pm 0.12$ & $0.77 \pm 0.11$ & $5.76 \pm 0.21$ & $1.46 \pm 0.16$ & $3.20 \pm 0.94$ & $1.37 \pm 0.11$ \\
$\mathrm{CM}$ & $1.52 \pm 0.31$ & $0.98 \pm 0.07$ & $7.95 \pm 0.51$ & $1.59 \pm 0.01$ & $4.66 \pm 1.23$ & $1.2 \pm 0.43$ \\
$\mathrm{TM}$ & $1.39 \pm 0.02$ & $0.96 \pm 0.13$ & $7.36 \pm 1.63$ & $2.01 \pm 0.27$ & $5.36 \pm 3.85$ & $1.66 \pm 0.08$ \\
\hline
\end{tabular}

$\mathrm{CF}=$ control female; $\mathrm{CM}=$ control male; $\mathrm{TF}=$ treated female; $\mathrm{TM}=$ treated male.

Data are expressed as mean \pm standard deviation $(\mathrm{SD}), \mathrm{n}=6$. 
TABLE VI - Effect of oral administration of atranorin (ATR) ( $5 \mathrm{~g} / \mathrm{kg}$-single dose) on hematological parameters, considering sex interaction, in Wistar rats $(\mathrm{n}=10)$

\begin{tabular}{lcccccc}
\hline \multicolumn{7}{c}{ Groups } \\
\hline Parameters & CF & TF & $\begin{array}{c}\text { UFS Female } \\
\text { Vivarium }\end{array}$ & CM & CT & $\begin{array}{c}\text { UFS Male } \\
\text { Vivarium }\end{array}$ \\
\hline Erythrocytes $\left(\times 10^{6} / \mathrm{mm}^{3}\right)$ & $7.12 \pm 0.17$ & $7.84 \pm 0.54$ & $7.3-8.64$ & $8.28 \pm 0.58$ & $8.80 \pm 0.39$ & $6.7-8.6$ \\
Hemoglobin $(\mathrm{g} / \mathrm{dl})$ & $15.3 \pm 0.21$ & $14.7 \pm 0.37$ & $13.2-15.1$ & $15.94 \pm 0.77$ & $15.8 \pm 0.61$ & $12.8-15.9$ \\
Hematocrit $(\%)$ & $40.65 \pm 0.91$ & $41.96 \pm 1.26$ & $39.1-48.5$ & $45.55 \pm 3.48$ & $44.45 \pm 1.37$ & $39.1-48.7$ \\
Leukocyte $\left(\times 10^{3} / \mathrm{mm}^{3}\right)$ & $7.10 \pm 0.14$ & $8.13 \pm 0.30$ & $4.7-12.98$ & $7.72 \pm 1.438$ & $9.70 \pm 1.43$ & $5.7-13.9$ \\
Neutrophil $(\%)$ & $12.5 \pm 0.63$ & $9.00 \pm 1.14$ & $5.4-37.5$ & $20.4 \pm 6.83$ & $14 \pm 5.65$ & $17.1-47.9$ \\
Lymphocyte (\%) & $85.5 \pm 4.94$ & $88.66 \pm 1.15$ & $57.9-90.0$ & $65.9 \pm 7.04$ & $84.02 \pm 8.61 *$ & $48.7-78.1$ \\
Eosinophil (\%) & $1 \pm 0$ & $1 \pm 0$ & $0.2-4.5$ & $1 \pm 0$ & $1 \pm 0$ & $0.3-4.0$ \\
Monocyte $(\%)$ & $1 \pm 0$ & $2 \pm 0$ & $0.6-7.9$ & $13.7 \pm 2.40$ & $12.75 \pm 3.5$ & $1.0-6.5$ \\
Basophil $(\%)$ & - & - & $0-0.8$ & - & - & $0-0.8$ \\
Atypical lymphocyte $(\%)$ & - & - & $0-1.0$ & - & - & $0-1.0$ \\
Platelets $\left(\times 10^{3} / \mathrm{mm}^{3}\right)$ & $741.00 \pm 12.72$ & $905.00 \pm 11.52$ & $757-1476$ & $735.20 \pm 20.21$ & $845.50 \pm 15.87$ & $837-1455$ \\
\hline
\end{tabular}

$\mathrm{CF}=$ control female $\mathrm{CM}=$ control male; $\mathrm{TF}=$ treated female; $\mathrm{TM}=$ treated male; $\mathrm{UFS}=$ Universidade Federal de Sergipe, Northeastern Brazil.

Data are expressed as mean \pm standard deviation $(\mathrm{SD}), \mathrm{n}=6$.

* Indicates statistical difference between control and ATR groups $(\mathrm{p}<0.05)$.

TABLE VII - Serum biochemical findings in rats treated with atranorin (ATR) at a single dose ( $5 \mathrm{~g} / \mathrm{kg}$ )

\begin{tabular}{|c|c|c|c|c|c|c|}
\hline \multicolumn{7}{|c|}{ Groups } \\
\hline Parameters & $\mathrm{FC}$ & FT & $\begin{array}{c}\text { UFS Female } \\
\text { Vivarium } \\
\end{array}$ & $\mathrm{MC}$ & MT & $\begin{array}{l}\text { UFS Male } \\
\text { Vivarium }\end{array}$ \\
\hline Urea (mg/dL) & $50.00 \pm 12.72$ & $35.66 \pm 4.50$ & $30-57$ & $37.3 \pm 4.16$ & $37.25 \pm 2.62$ & $30-42$ \\
\hline Creatinine (mg/dL) & $0.51 \pm 0.14$ & $0.5 \pm 0.10$ & $0.4-0.7$ & $0.4 \pm 0.04$ & $0.37 \pm 0.05$ & $0.44-0.64$ \\
\hline Total Protein $(\mathrm{g} / \mathrm{dL})$ & $6.00 \pm 0.28$ & $4.62 \pm 3.19$ & $6.1-7.4$ & $5.38 \pm 0.32$ & $5.8 \pm 0.31^{*}$ & $5.4-6.6$ \\
\hline Globulin (g/dL) & $4.85 \pm 0.21$ & $4.56 \pm 0.46$ & $3.1-4.3$ & $4.36 \pm 0.24$ & $4.5 \pm 0.31$ & $2.7-3.5$ \\
\hline Albumin (g/dL) & $1.15 \pm 0,07$ & $1.35 \pm 0.12$ & $2.6-3.4$ & $1.02 \pm 0.10$ & $1.3 \pm 0,00^{*}$ & $2.7-3.2$ \\
\hline $\operatorname{AST}(\mathrm{U} / \mathrm{L})$ & $110.00 \pm 0.56$ & $95.66 \pm 10.21$ & $83-184$ & $122.71 \pm 45.46$ & $120.50 \pm 32.46$ & $81-180$ \\
\hline $\operatorname{ALT}(\mathrm{U} / \mathrm{L})$ & $63.01 \pm 0,03$ & $55.66 \pm 11.93$ & $26-60$ & $70.80 \pm 23.73$ & $77.50 \pm 21.62$ & $36-58$ \\
\hline GGT (U/L) & $9.51 \pm 0.70$ & $8.01 \pm 1.73$ & -- & $8.90 \pm 1.37$ & $7.25 \pm 1.70$ & \\
\hline TBil (mg/dL) & $0.54 \pm 0.03$ & $0.56 \pm 0.02$ & $0.07-0.09$ & $0.25 \pm 0.05$ & $0.46 \pm 0.23 *$ & $0.07-0.08$ \\
\hline $\operatorname{DBil}(\mathrm{mg} / \mathrm{dL})$ & $0.11 \pm 0$ & $0.06 \pm 0.04$ & $0.01-0.03$ & $0.17 \pm 0.01$ & $0.05 \pm 0.02 *$ & $0.01-0.03$ \\
\hline IBil (mg/dL) & $0.43 \pm 0.03$ & $0.5 \pm 0.02$ & $0.01-0.01$ & $0.51 \pm 0.28$ & $0.41 \pm 0.20$ & $0.01-0.01$ \\
\hline $\operatorname{ALP}(\mathrm{U} / \mathrm{L})$ & $91 \pm 9.89$ & $95.66 \pm 21.59$ & $63-138$ & $89.2 \pm 28.09$ & $153.25 \pm 15.26^{*}$ & $79-196$ \\
\hline LDH (U/L) & $772.00 \pm 244.65$ & $841.33 \pm 371.81$ & -- & $1563.0 \pm 188.0$ & $1170.5 \pm 225.5$ & -- \\
\hline $\mathrm{Ca}^{2+}(\mathrm{mEq} / \mathrm{L})$ & $9.75 \pm 0.21$ & $10.51 \pm 0.41$ & -- & $10.49 \pm 0.28$ & $10.52 \pm 0.29$ & -- \\
\hline $\mathrm{Na}^{+}(\mathrm{mEq} / \mathrm{L})$ & $135.50 \pm 0.70$ & $136.66 \pm 0.57$ & $132-146$ & $140.2 \pm 1.31$ & $136.5 \pm 1.00 *$ & $132-146$ \\
\hline $\mathrm{K}^{+}(\mathrm{mEq} / \mathrm{L})$ & $4,25 \pm 0,21$ & $5,8 \pm 1,53$ & $3.7-5.7$ & $5,79 \pm 1,55$ & $5.35 \pm 1.19$ & $3.7-5.7$ \\
\hline Uric acid (mg/dL) & $1.4 \pm 0.28$ & $1.54 \pm 0.68$ & $1.2-2.5$ & $2.49 \pm 1.26$ & $1.30 \pm 0.43$ & $0.9-2.0$ \\
\hline
\end{tabular}

$\mathrm{ALP}=$ alkaline phosphatase; $\mathrm{ALT}=$ alanine aminotransferase; $\mathrm{AST}=$ aspartate aminotransferase; $\mathrm{CF}=$ control female; $\mathrm{CM}=$ control male; DBil = direct bilirubin; GGT = gamma-glutamyl transferase; IBil = indirect bilirubin; $\mathrm{LDH}=$ lactate dehydrogenase; TBil $=$ total bilirubin; $\mathrm{TF}=$ treated female; TM $=$ treated male; UFS $=$ Universidade Federal de Sergipe, Northeastern Brazil.

Data are expressed as mean \pm standard deviation (SD), $\mathrm{n}=6$.

* Indicates statistical difference between control and ATR groups $(\mathrm{p}<0.05)$. 
cells. ATR cytotoxicity on the growth of L929 cells is shown in Figure 5. Cell proliferation was analyzed $24 \mathrm{~h}$ after L929 cells had been cultured with ATR at 0.01, 0.02, $0.04,0.08$, and $0.16 \mathrm{mg} / \mathrm{mL}$ using MTT assay. ATR at concentrations of $0.01-0.16 \mathrm{mg} / \mathrm{mL}$ did not show cytotoxic effects on the L929 cell line. These results suggest that ATR has no cytotoxic effects at these concentrations. Melo et al. (2011) reported an effect of ATR on SH-SY5Y cultures, a neuroblastoma-derived catecholaminergic cell line.

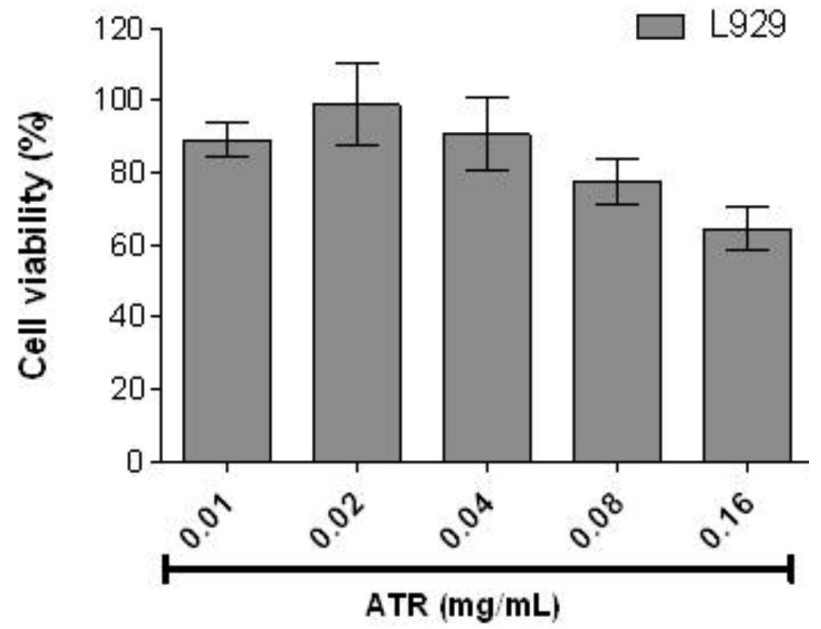

FIGURE 5 - Cytotoxic effect of atranorin (ATR) in L929 cell line. Each value represents the mean \pm standard deviation (SD). ATR was dissolved in $12.5 \%$ dimethylformamide in the middle of the cell. The cytotoxicity of the solvent of these two cell lines and L929 (fibroblast) was evaluated. The concentration of $12.5 \%$ in the cells was not toxic.

Different concentrations of ATR alone had no effect on cell viability, as assessed by MTT assay. When cells are treated with $\mathrm{H}_{2} \mathrm{O}_{2}$, there is a significant decrease in cell viability to $40 \%$ of control levels. Co-incubation with ATR protects SH-SY5Y cells against the cytotoxic effects of $\mathrm{H}_{2} \mathrm{O}_{2}$. Nonetheless, all ATR concentrations reversed the effect of $\mathrm{H}_{2} \mathrm{O}_{2}$ (Melo et al., 2011).

\section{CONCLUSION}

In summary, data from the present study indicated that ATR has anti-inflammatory properties, but further studies are necessary to establish its correct mechanism of action. It is possible to speculate about the inhibition of the synthesis of many inflammatory mediators involved in cell migration. Additionally, there were no relevant signs or significant changes in hematological, biochemical, and histopathological parameters resulting from the long-term administration of ATR. It is therefore concluded that ATR, at the doses used in this study, produced no remarkable toxic effects on rats and might be an important tool in the management and/or treatment of inflammatory disorders.

\section{ACKNOWLEDGEMENTS}

We would like to thank the National Council for Scientific and Technological Development (Conselho Nacional de Desenvolvimento Científico e Tecnológico/ $\mathrm{CNPq} /$ Brazil) and the Foundation for Research Support of the State of Sergipe (Fundação de Amparo à Pesquisa do Estado de Sergipe/FAPITEC-SE) for the financial support.

\section{REFERENCES}

ALMEIDA, R.N.; FALCÃO, A.C.G.M.; DINIZ R.S.T.; QUINTANS-JUNIOR, L.J.; POLARI, R.M.; BARBOSAFILHO, J.M.; AGRA, M.F.; DUARTE, J.C.; FERREIRA, C.D.; ANTONIOLLI, A.R.; ARAÚJO, C.C. Metodologia para avaliação de plantas com atividade no sistema nervoso central e alguns dados experimentais. Rev. Bras. Farm., v.80, p.72-76, 1999.

BARNES, J., HAWKSWORTH, D., SHAW, C., HIDER, B., KINGHORN, D. Pharmacognosy in the 21 st century. Pharm. J., v.264, p.701-703, 2000

BASTOS, L.F.; MERLO, L.A.; ROCHA, L.T; COELHO, M.M. Characterization of the antinociceptive and antiinflammatory activities of doxycycline and minocycline in different experimental models. Eur. J. Pharmacol., v.576, p.171-179, 2007.

BRASIL. Ministério da Saúde. Agência Nacional de Vigilância Sanitária. Resolução no. 90 de 16 de março de 2004. Dispõe sobre o Guia para os estudos de toxicidade de medicamentos fitoterápicos. Diário Oficial da União. Poder Executivo. Brasília, Distrito Federal, 18 mar. 2004. Seção I, p.34.

BUGNI, T.S.; ANDJELIC, C.D.; POLE, A.R.; RAI, P.; IRELAND, C.M.; BARROWS, L.R. Biological active components of a Papua New Guinea analgesic and antiinflammatory lichen preparation. Fitoterapia, v. 80, p.270273, 2009.

CHANG-GUE, S.; SEUNG-HYUN, H.; JUNG-HYO, C.; JANG-WOO, S.; CHIN-HO, C.; YEON-WEOL, L.; CHONG-KWAN, C. Induction of hemopoiesis by saenghyuldan, a mixture of Ginseng radix, Paeoniae radix alba, and Hominis placenta extracts. Acta Pharmacol. Sin., v.24, p.120-126, 2003. 
DANIELS, B.S.; HOSTETTER, T.H. Adverse effects of growth in the glomerular microcirculation. Am. J. Physiol., v.258, p.1409-1416, 1990.

DI ROSA, M.; SORRENTINO, L. The mechanism of the inflammatory effect of carrageenan. Eur. J. Pharmacol., v.4, p.340-342, 1968.

FALCÃO, E.P.S.; SILVA, N.H.; GUSMÃO, N.B.; RIBEIRO, S.M.; PEREIRA, E.C. Atividade antimicrobiana de derivados fenólicos de Ramalina Sorediosa (B. de Lesd) Laundron. Acta Bot. Bras., v.18, p.911-918, 2004.

FERNANDEZ, E.; REYES, A.; HIDALGO, M.E.; QUILHOT, W. Photoprotector capacity of lichen metabolites assessed through the inhibition of the 8-methoxypsoralen photobinding to protein. J. Photoch. Phombiol. B: Biol., v.42, p.195-201, 1998.

FOTAKIS, G.; TIMBRELL, J.A. In vitro cytotoxicity assays: Comparison of LDH neutral red, MTT and protein assay in hepatoma cell lines following exposure to cadmium chloride. Toxicol. Lett., v.160, p.171-177, 2006.

GAD, S.C. The rat: pathology. In: GAD, S.C.; CHENGELLIS, C.P. (Eds.). Animal models in toxicology. New York: Marcel Dekker, 1992. 217 p.

HENRY, J. Diagnósticos clínicos e tratamento por métodos laboratoriais. 20. ed. São Paulo: Manole. 2008. 1794 p.

HIDALGO, M.E.; FERNÁNDEZ, E.; QUILHOT, W.; LISSI, E. Antioxidant activity of depsides and depsidones. Phytochemistry, v.37, p.1585-1587, 1994.

HONDA, N.K.; VILEGAS, W. A química dos liquens. Quím. Nova, v.21, p.110-125, 1999.

HONEGGER, R. Functional aspects of the lichen symbiosis. Plant Mol. Biol., v.42, p.553-578, 1991.

HOSSNE, W.S.; SPADELLA, C.T.; BACCHI, C.E. Estudo biométrico de comprimento, peso corpóreo e peso de órgãos em animais de experimentação biomédica. I. Rato. Rev. Ciênc. Biom., v.7, p.1-19, 1986/1987.

HOWELL, G.M.; EDWARDS, NEWTON, E.M.; WYNNWILLIAMS, D.D. Molecular structural studies of lichen substances II: atranorin, gyrophoric acid, fumarprotocetraric acid, rhizocarpic acid, calycin, pulvinic dilactone and usnic acid. J. Mol. Structure, v.651-653, p.27-37, 2003.
HUNECK, S. The significance of lichens and their metabolites. Naturwissenschaften, v.86, p.559-570, 1999.

KUMAR, K.C.; MULLER, K. Lichen metabolites. 1. Inhibitory action against leukotriene B4 biosynthesis by a non-redox mechanism. J. Nat. Prod., v.62, p.817-820, 1999.

LORAM, L.C.; FULLER, A.; FICK, L.G.; CARTMELL, T.; POOLE, S.; MITCHELL, D. J. Cytokine profiles during carrageenan-induced inflammatory hyperalgesia in rat muscle and hind paw. Pain, v.8, p.127-136, 2007.

LUSTER, A.D.; ALON, R; VON, ANDRIAN, U.H. Immune cell migration in inflammation: Present and future therapeutic targets. Nat. Immunol., v.6, p.1182-1190, 2005.

MAIA, M.B.S.; SILVA, N.H.; SILVA, E.F.; CATANHO, M.T.J.; SCHULER, A.R.P.; PEREIRA, E.C. Antinoceptive activity of crude extract and atranorin obained from the lichen Cladina dendroides (des Abb.). Acta Farm. Bonaerense, v.21, n.4, p.259-264, 2002.

MELO, M.G.D.; ARAÚJO,A.A.S.; ROCHA, C.P.L.; ALMEIDA, E.M.S.A.; SIQUEIRA, R.S.; BONJARDIM, L.R.; QUINTANS-JÚNIOR, L.J. Purification, physicochemical properties, thermal analysis and antinociceptive effect of atranorin extracted from Cladina kalbii. Biol. Pharm. Bull., v.31, p.1977-1980, 2008.

MELO, M.G.D., SANTOS, J.P.A, SERAFINI, M.R., CAREGNATO, F.F., PASQUALI, M.A.B., RABELO, T.K., ROCHA, R.F., QUINTANS-JÚNIOR, L.J., SILVA, F.A., ARAUJO, A.A.S., MOREIRA, J.C.F. and GELAIN, D.P. Redox properties and cytoprotective actions of atranorin, a lichen secondary metabolite. Toxicol. in vitro, v.25, p.462468, 2011.

MITRUKA, B.M.; RAWNSLEY, H.M. Clinical, biochemical and hematological reference values in normal experimental animals and normal humans. 2.ed. New York: Masson, 1981. p.65.

MORRIS, M.W.; DAVEY, F.R. Exame básico de sangue. In: HENRY, J.B. (Ed.). Diagnósticos clínicos e tratamento por métodos laboratoriais. 19.ed. São Paulo: Manole, 1999. p.1552.

MOTTA, V. T. Bioquímica clínica para laboratório: princípios e interpretações. 4.ed. Porto Alegre: Médica Missau, 2003. 419 p. 
PEREIRA, E.C. Lichens from Brazilian Northeast (NE) - studies and applications. In: MARCELLI, M.P., SEAWARD, M.R.D. (Eds.). Lichenology in Latin America: history, current knowledge and applicaton. São Paulo: Cetesb, 1998. p.65-70.

RIBEIRO, S.M.; PEREIRA, E.C.G.; NICÁCIO, S.; FALCÃO, E.P.; GUSMÃO, N.B.; HONDA, N.; QUILHOT, W. Mitteinluger aus dem Institute fur Allgemeline. Bot. Hamburg, v.30-32, p.187-194, 2002.

SALVEMINI, D.; WANG, Z.Q.; WYATT, P.S.; BOURDON, D.M.; MARINO, M.H.; MANNING, P.T., CURRIE, M.G. Dual inhibition of nitric oxide and prostaglandin production contributes to the anti-inflammatory properties of nitric oxide synthase inhibitors. Br. J. Pharmacol., v.118, p.829838, 1996.

SCHALM, O.W. Veterinary hematology. 4.ed. Philadelphia: Lea \& Febiger, 1986. p.1221.

SIQUEIRA, R.S.; BONJARDIM, L.R.; ARAÚJO, A.A.S.; ARAÚJO, B.E.S.; MELO, M.G.D.; OLIVEIRA, M.G.B.; GELAIN, D.P.; SILVA, F.A.; DE SANTANA, J.M.; ALBUQUERQUE-JUNIOR, R.L.C.; ROCHA, R.F.; MOREIRA, J.C.F.; ANTONIOLLI, A.R.; QUITANSJUNIOR, L.J. Antinociceptive activity of atranorin in mice orofacial nociception tests. Z. Naturforsch. C., v.65c, p.551-561, 2010.
UDUT, E.V.; ZHDANOV, V.V.; GUR'IANTSEVA, L.A.; MINAKOVA, M.I.; DYGAI, A.M. Mechanisms of the erythropoiesis-stimulating effect of skull cap (scutellaria baicalensis) extract. Eksperim. Klinich. Farmak., v.68, p.9-15, 2005.

VINEGAR, R.; SCHREIBER, W.; HUGO, R. Biphasic development of carrageenan-induced demain the hind paw of the rats as an assay for anti-inflammatory drugs. Proc. Soc. Exp. Biol. Med., v.111, p.544-547, 1962.

WINTER, C.A.; RISELEY, E.A.; NUSS, G.W. Carrageenaninduced edema in the hind paw of the rats as an assay for anti-inflammatory drugs. Proc. Soc. Exp. Biol. Med., v.111, p.544-547, 1962.

Received for publication on $11^{\text {th }}$ November 2011 Accepted for publication on $06^{\text {th }}$ June 2011 